\title{
Porosity Identification of Carbonate Core Reservoir Using Digital Rock Physics Method
}

\author{
Irsyad Nuruzzaman Sidiq*, Thaqibul Fikri Niyartama \\ Physics Department, Faculty of Science and Technology, UIN Sunan Kalijaga Yogyakarta \\ J1. Marsda Adisucipto No 1 Yogyakarta 55281, Indonesia. Tel. +62-274-540971, Fax. +62-274-519739. \\ *Email: irsyadsidiq80@gmail.com
}

\begin{abstract}
Sidiq I N, Niyartama T F. 2017. Porosity Identification of Carbonate Core Reservoir Using Digital Rock Physics Method. Proc Internat Conf Sci Engin 1: 175-181. Indonesia is an archipelago country so rich with coral reefs that are a major component of the carbonate rock constituents. Where as much as $40 \%$ of carbonate rocks in Indonesia is a hydrocarbon reservoir is still rarely done exploration. This is because conventional hydrocarbon exploration technology has not been able to provide detailed information about the physical quantities. Hydrocarbon exploration technologies currently leads on digital technology to know the physical quantities of a reservoir of more detail such as porosity. Porosity which is physical quantities related to the presence of hydrocarbons in the pores of rocks. Digital Rock Physics (DRP) is a digital image-based method as an alternative method to find the physical quantities of rock samples to make it more effective and efficient. This study aims to identify the physical quantity using the method of porosity of the DRP until obtaining porosity of rock core carbonate reservoir by analyzing the binary image of the two rock cores from the same reservoir but has different dimensions to find out the exact core rocks to analyze the value of porosity. Binary image obtained from a scanned image of a projection of rock that has been reconstructed to become the greyscale image and have gone through the process of thresholding. The results of this study showed that the method can identify the physical quantities of DRP porosity and non-damaging rock pore structure (non-destructive). Analysis of the porosity of the rock core with histogram variations performed (by adjustingting the histogram), using the otsu method of thresholding and pixel size of the image has high $(5.343750 \mu \mathrm{m})$ used to analyze the value of porosity. The porosity values acquired for 18.040 and has precision $96.20 \%$.
\end{abstract}

Keywords: Digital Rock Physics (DRP), reservoir, carbonate, porosity

\section{INTRODUCTION}

Study of carbonate rocks in Indonesia, especially in the field of Geophysics is still very lacking. In the meantime, Indonesia is in a tropical region is an ideal place for the formation of coral reefs. Whereas coral reefs are the main component of the carbonate rock. Carbonate rock in Indonesia is important to be examined primarily in the petroleum industry because it acts as a reservoir, where nearly $40 \%$ of the existing reservoir rocks in carbonate rocks originating from the world. While in Indonesia itself, the oil and gas consumption has continued to increase since the year 2003 of around $8 \%$ per year while the production is always decreased $15-20 \%$ per year. This is because national oil reserves currently living 3.7 billion barrels from about 27 billion barrels of proven oil reserves (proven reserve) (Biantoro, 2015). Hydrocarbon exploration methods currently obtain information about physical magnitudes more detailed hydrocarbon exploitation activities so that it cannot be the maximum. That is because the reservoir rocks must have the ability to store fluid properly, then called porosity. Porosity is a physical quantity that is important in the exploration of hydrocarbons. Therefore, the required method of hydrocarbon exploration that is capable of providing information on physical quantities especially porosity so that exploitation activities more efficient and effective. Such methods are Digital Rock Physics (DRP). Digital Rock Physics (DRP) is a digital image-based method as an alternative method to find the physical quantities of rock samples to make it more effective and efficient (Winardhi, 2016). The purpose of this study is to identify the physical magnitudes of porosity and calculate the value of a core sample of the carbonate reservoir porosity as well as calculating the accuracy value calculation results between laboratory results with the results of the digital.

\section{MATERIALS AND METHODS}

The data used in this study is the core samples reservoir of carbonate rock coded $\mathrm{C} 30$ with different dimensions as shown by Table 1. Two samples are named sample I and D. Sample D is part of the sample I that have gone through the process of plugging.

Table 1. Dimensions of sample I and D.

\begin{tabular}{ccc}
\hline Sample & Diameter $(\mathbf{c m})$ & Length $(\mathbf{c m})$ \\
\hline I & 3,750 & 5,025 \\
D & 0,660 & 0,854 \\
\hline
\end{tabular}

Both of these samples were carried out scanning processes using Micro-CT Scan-type Sky Scan 1173 (Figure 1). This device is located in the building of BSC A ITB. Scanning scenarios used are full single scenario as shown by Figure 2 . 


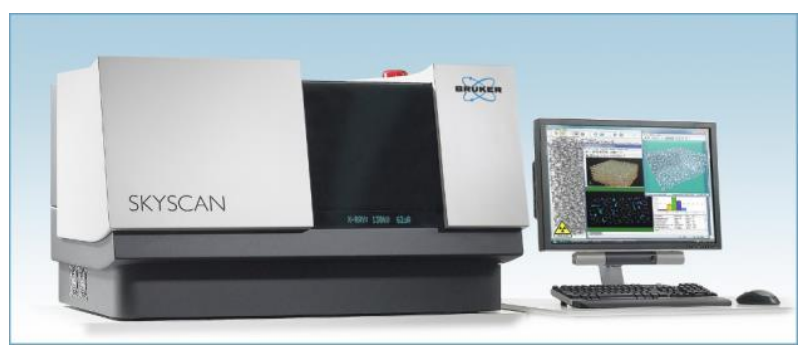

Figure 1. Bruker Micro-CT Scan Sky Scan 1173 (taken from http://bruker-microct.com/product/1173.htm).

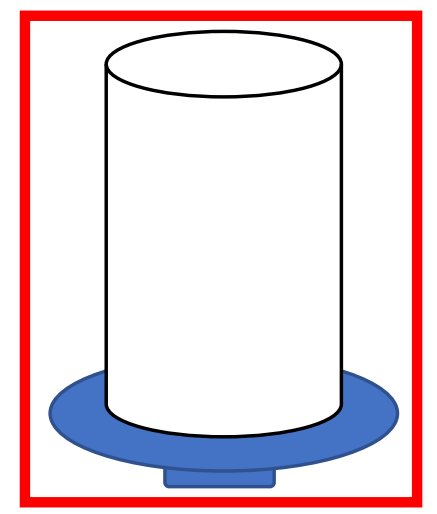

Figure 2. Single full scanned scenario.

The projected image of scanned image are then conducted of the reconstruction process to generate greyscale image. This study used the NRecon software for reconstruction based on Fieldkamp algorithm which is the derived from the Filtered Back-Projection (FBP) algorithm and has been adapted to the geometry of a rotating object (Winardhi, 2016). Histogram variations are also done at this stage. Then, greyscale image through VOI process to select parts of the image that want to be calculated. The next process is bitwise operation to remove an area on the image that will not be calculated. Then greyscale image is through of thresholding process to yield a binary image. There are two kinds of thresholding methods are used, namely the otsu method and adaptive method. Thresholding method variation aims to find out the similarities between the lateral image of image greyscale with binary image. This binary image that used to identification process of physical quantity of reservoir rock core samples of carbonate. The value of porosity $(\phi)$ calculated using the equation:

$$
\phi=\frac{v_{p}}{v}
$$

Porosity that used in this study is the value of the total porosity. Total porosity is porosity related to all spaces pores, holes, cracks and more. Total porosity is the sum of the primary and secondary porosity. The value of porosity for carbonate rocks ranging from 525\% (Coneybeare, 1967 and Keelan, 1982). According to Koesoemadinata (1980), porosity on the reservoir are categorized as shown in Table 2.

Table 2. Porosity on the reservoir (Koesoemadinata, 1980).

\begin{tabular}{ll}
\hline Porosity (\%) & Description \\
\hline $0-5$ & Ignored \\
$5-10$ & Bad \\
$10-15$ & Enough \\
$15-20$ & Good \\
$20-25$ & Very Good \\
$>25$ & Excellent \\
\hline
\end{tabular}

On digital image analysis method, pore volume is obtained by counting the number of pixels that are black and the total volume obtained from the overall number of pixels in a predefined VOI. Afterwards calculate the precision between the laboratory results with the results of this study on digital using the following equation:

accuracy $=\frac{\text { digital value-Iabvalue }}{\text { Iabvalue }} \times 100 \%$

\section{RESULTS AND DISCUSSION}

\section{Results}

\section{Histogram Variations}

Histogram variations aim to know the distribution pixels intensity values of the image projection. The distribution of pixels intensity values is relate the dark brightness image. When the histogram curve is varied, so the intensity curve also changed. Histogram variations to the sample I and D as presented in Table 3 and Table 4. 
Table 3. Histogram variations of image projection without adjusting histogram.

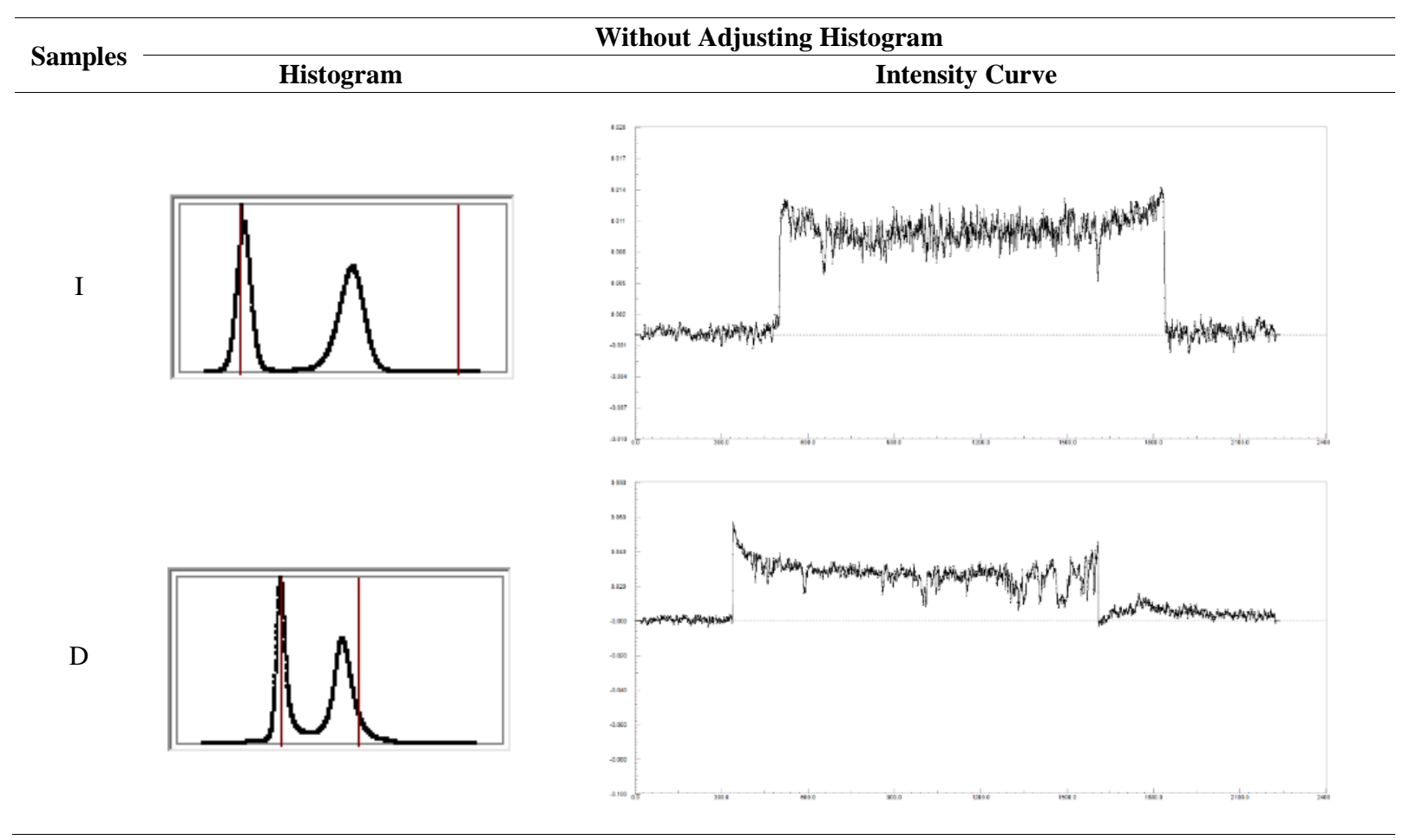

Table 4. Histogram variations of image projection with adjusting histogram.

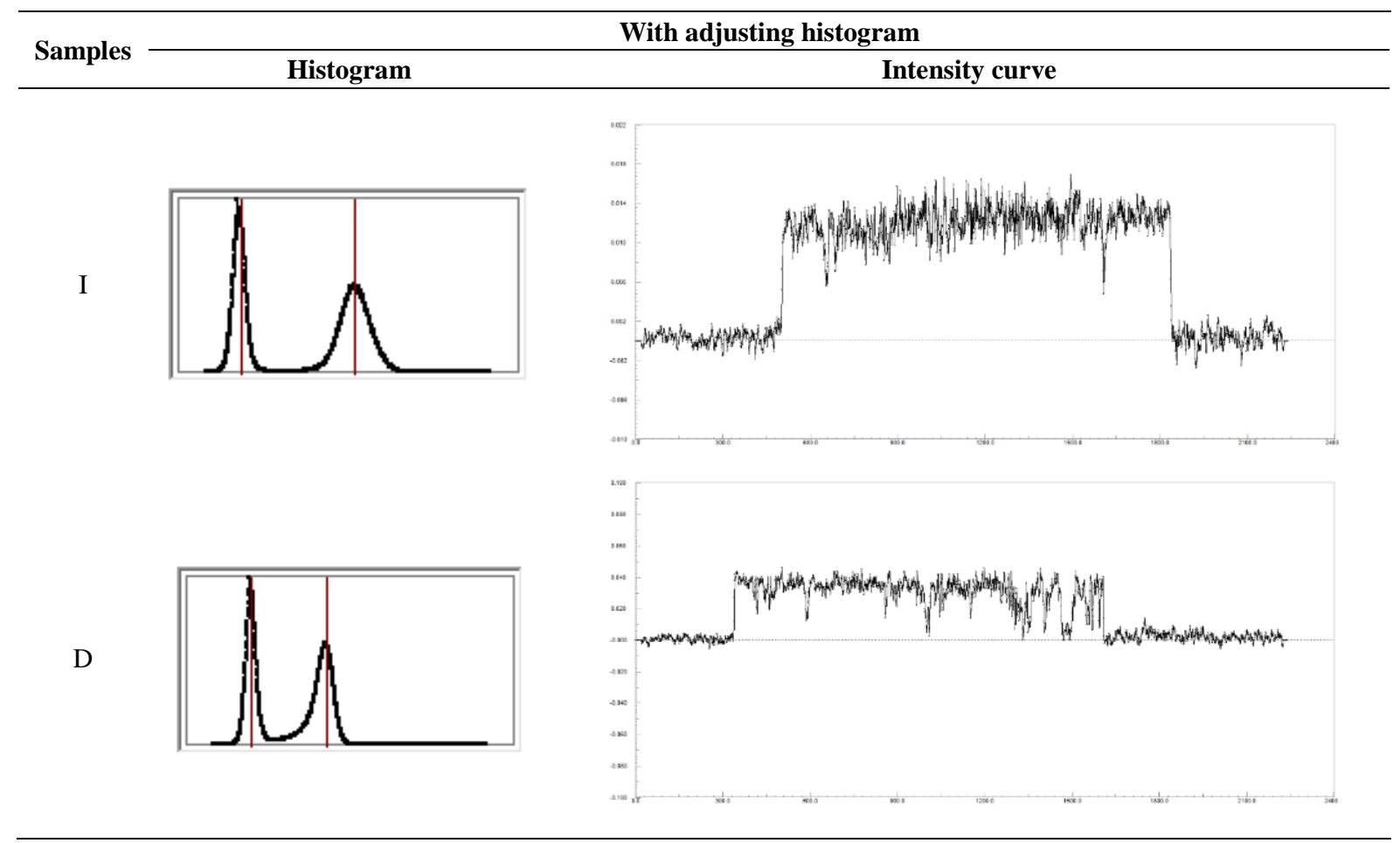

From the Table 3 and Table 4 it can be seen that the histogram variations can affect the intensity curve. When the histogram is not adjusting, then distribution of the pixels intensity values pile up at one point (not evenly), this can be seen from the intensity curve concave to the image of the both samples. But if adjusting the histogram between peak to peak, then distribution of pixels intensity values become evenly. It can be seen from the both samples of image intensity curve. 


\section{Porosity Analysis}

Porosity values analysis from binary image of the core sample of carbonate reservoirs using CT-Analyser software 1.13 obtained porosity values for the two samples, core I and D. The result of porosity value analysis for each sample is different because influenced by adjustingting the histogram, as are presented as follows:

\section{- Without Adjusting Histogram}

Porosity values of binary image samples from carbonate reservoir cores without adjusting histogram obtained results are presented in Table 5 for the sample I and Table 6 for sample D.

Table 5. Porosity value of sample I.

\begin{tabular}{lll}
\hline Thresholding method & Adaptive (mean of min and max values) \\
\hline Binnary image & & \\
Total porosity value (\%) & & \\
\hline
\end{tabular}

Tabel 6. Nilai porositas sampel D.

\begin{tabular}{|c|c|c|}
\hline Thresholding method & Otsu & Adaptive (mean of min and max values) \\
\hline Binnary image & & \\
\hline Total porosity value $(\%)$ & 18,102 & 20,792 \\
\hline
\end{tabular}

\section{- With Adjusting Histogram}

Porosity values of binary image samples from carbonate reservoir cores without adjusting histogram obtained results are presented in Table 7 for the sample I and Table 8 for sample D.

Tabel 7. Porosity value of sample I.

\begin{tabular}{lll}
\hline Thresholding method & Adsu & Adive (mean of min and max values) \\
Binnary image & &
\end{tabular}


Tabel 8. Porosity value of sample I.

\begin{tabular}{|c|c|c|}
\hline Thresholding method & Otsu & Adaptive (mean of min and max values) \\
\hline Binnary image & & \\
\hline Total porosity value (\%) & 18,040 & 21,369 \\
\hline
\end{tabular}

The results of the porosity analysis which has been shown by Table 5, Table 6, Table 7 and Table 8 written in summary in Table 9 as follows:

Table 9. Total porosity value (\%).

Total porosity value based on image $(\%)$

\begin{tabular}{cccccc}
\cline { 2 - 4 } Samples & \multicolumn{2}{c}{ Otsu } & \multicolumn{2}{c}{ Adaptive (mean of min and max values) } & $\begin{array}{c}\text { Total porosity value } \\
\text { based on lab (\%) }\end{array}$ \\
\cline { 2 - 4 } & $\begin{array}{c}\text { Without adjusting } \\
\text { histogram }\end{array}$ & $\begin{array}{c}\text { With adjusting } \\
\text { histogram }\end{array}$ & $\begin{array}{c}\text { Without adjusting } \\
\text { histogram }\end{array}$ & $\begin{array}{c}\text { With adjusting } \\
\text { histogram }\end{array}$ & \\
\hline I & 18,116 & 18,097 & 21,942 & 22,354 & 17,379 \\
D & 18,174 & 18,040 & 20,792 & 21,369 & \\
\hline
\end{tabular}

From the results of the porosity analysis that has been presented by the Table 9, then calculated the accuracy values of porosity in digital laboratory and the results are presented in Table 10 below:

Table 10. Accuracy value of total porosity (\%).

\begin{tabular}{|c|c|c|c|c|c|}
\hline Parameter & Total porosity value $(\%)$ & $\mathbf{I}$ & Accuracy (\%) & D & Accuracy (\%) \\
\hline \multirow{2}{*}{ Otsu } & Without adjusting histogram & 18,116 & $95,76 \%$ & 18,174 & $95,43 \%$ \\
\hline & With adjusting histogram & 18,097 & $95,87 \%$ & 18,040 & $96,20 \%$ \\
\hline \multirow{2}{*}{$\begin{array}{l}\text { Adaptive (mean of min } \\
\& \text { max values) }\end{array}$} & Without adjusting histogram & 21,942 & $73,74 \%$ & 20,792 & $80,36 \%$ \\
\hline & With adjusting histogram & 22,354 & $71,37 \%$ & 21,369 & $77,04 \%$ \\
\hline
\end{tabular}

: Total porosity values the most approaching the value of porosity of the laboratory.

From Table 10 appear that porosity value of sample D by using otsu method of thresholding and by adjusting the histogram more approximate to porosity value of laboratory with the result of total porosity has $18.040 \%$ and has a accuracy of $96.20 \%$. Therefore, the porosity value of sample $\mathrm{D}$ has represented the throughout sample I so that it can be concluded that the porosity value analysis by using otsu method of thresholding and by adjusting the histogram is right used to core samples of carbonate rock reservoir coded $\mathrm{C} 30$.

\section{Discussions}

\section{Histogram Variations}

Histogram variations are simultaneously done with the adjustingtings parameter reconstruction of image projection. In this study, there are two types of histograms of two samples that is I and D. Histogram variations of intensity curves obtained for each sample as shown in Table 3 and Table 4 . The intensity curve shows the distribution in the intensity of the pixel values. 
From the Table 3 it can be seen that the resulting intensity curve without adjusting the histogram on the samples I was not flat, but is concave with a tendency towards the right. This shows the distribution of the pixels intensity builds up to the right and left. This happens because the histogram on the sample image has distribution that accumulates on the right side (shown by the red line), and thus tend to look darker. This also applies equally in the image of the sample D as shown in Table 4, where the pixels at the edges of stacked up right and left. This is because the histogram of the image of the sample is heaped on the right where the large intensity. As a result, the image tends to be darker.

In contrast to the curve intensity of the resulting without adjusting the histogram, the curve intensity generated by adjusting the histogram looks flat as shown in Table 4. The histogram is adjusting to peak with low intensity to high intensity peaks. This was done because in the area there are number of pixels. Curve intensity looks flat, this shows the intensity distribution evenly. Distribution which is evenly make the image look more emphatic distinction of density. Therefore, in this study the variation of the histogram by adjusting the histogram correspond to samples of carbonate rock reservoir cores coded C30.

\section{Porosity Analysis}

Before the porosity analysis process, greyscale image that comes from the reconstruction image carried out process of thresholding. Thresholding method that used in this study are otsu method and adaptive (mean of min $\&$ max values). Both of these methods use because they have different ways of segmenting each other. Binary image resulting from the otsu method and adaptive (mean of min \& max values) can be seen in Table 5, Table 6 are without adjusting the histogram and Table 7, Table 8 by adjusting the histogram.

From these tables look that binary image that using the otsu method results more equal with the original image (reconstruction) compared to using adaptive method (mean of min \& max values). Otsu method doing segmentation globally, all of 2D image of the whole will be segmentation by using a single threshold value for each pixel in the image. This makes the entire image thresholding process completed quickly. Besides that, this method more equal with histogram adjusted peak to peak as shown in Table 7 and Table 8 . While the adaptive (mean of $\min \& \max$ values) doing segmentation with block on the image. Each block will look for the appropriate threshold values. Whereas the threshold for each block can be different and may also be the same. Because adaptive method (mean of min \& max values) very detail in the process of thresholding, then the value of the total porosity of binary images using adaptive method (mean of min \& max values) is greater than with the use otsu method. In addition, it takes quite a long time in the process of thresholding segmentation because that is done very much (details). Therefore, the image of carbonate reservoir core samples coded C30 better suited using the method of otsu.

Then, analysis of binary image to get the total porosity values from each sample. Binary image analysis performed using 3D Analysis in CT-Analyser software. The result of porosity value contained in Table 9. If the porosity value compared between sample I and sample $\mathrm{D}$, so the porosity value of sample $\mathrm{D}$ is closer to the porosity value results of laboratory. This is because the sample I have a lower image resolution compared to a sample of $\mathrm{D}$. This is apparent also from the pore structure in both samples, indicated by the Figure $3 a$ and $3 b$.
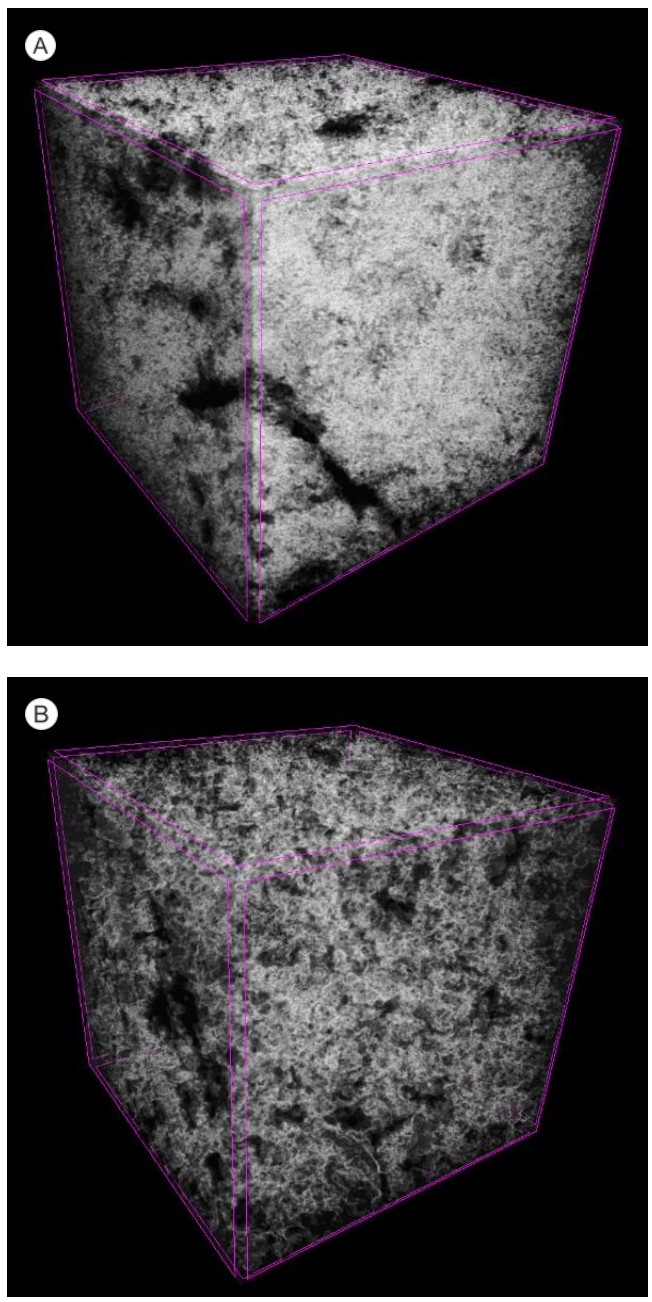

Figure 3. 3D pore structure of sample I (A) sample D (B).

Light colors on the Figure $3 \mathrm{a}$ and Figure $3 \mathrm{~b}$ shows the matrix on the rocks while the dark color shows the porous structure of the sample. The samples I have a porous structure that is not interconnected if compared to the sample D. It is apparent from the number of matrices on the samples I look more compared with samples of D. It is indicative of some of the missing information. This happens because the samples I have a low resolution $28.145463 \mu \mathrm{m}$ whereas the sample D has a high resolution $5.343750 \mathrm{~m}$. High Resolution means having a very small pixel sizes, so that the information contained in the image will be more detail. Therefore, 
porous structure sample D interconnected compared samples I. Pore structure connected closely related to connect or not the pore in the sample. Pores interconnected relate to permeability of this because the permeability are associated with the permit of oil and gas that is in the sample. So the total porosity values between digital image with the laboratory for sample D by adjusting the histogram has a closeness with the value of the accuracy of $96.20 \%$ as shown by Table 10 .

From the explanation that has been presented above, the right of the histogram variations used in this study is to adjusting the histogram. The exact method used in this study on thresholding process is otsu method. Samples with porosity value approaching most laboratories is sample $\mathrm{D}$ because it has a high image resolution with the total porosity value $18.040 \%$. When compared to the reservoir porosity Koesoemadinata (1980) in Table 2.2, the reservoir core samples of carbonate rock has sufficient porosity. This allows oil and gas saved a lot. Thus it can be concluded that the method of the Digital Rock Physics (DRP) was able to identify physical quantity porosity with obtained the porosity value most approaching the porosity value of laboratory is sample D with variations of the histogram is by adjusting histogram and otsu thresholding method of use has a porosity value $18.040 \%$. The sample was representative of the overall value of the total porosity of samples of carbonate reservoir cores are used coded C30.

\section{CONCLUSIONS}

The results of this study showed that the method can identify the physical quantities of DRP porosity and non-damaging rock pore structure (non-destructive). Analysis of the porosity of the rock core with histogram variations performed (by adjustingting the histogram), using the otsu method of thresholding and pixel size of the image has high $(5.343750 \mu \mathrm{m})$ used to analyze the value of porosity. The porosity values acquired for 18.040 and has precision $96.20 \%$.

\section{ACKNOWLEDGEMENTS}

Thank you to the LEMIGAS Jakarta has rent the carbonate rock core samples as well as a data point, and to Dr. Fourier Eljabbar Dzar Latief who have helped and gave directives to the author in the process retrieval of image and of processing.

\section{REFERENCES}

Anggraeni, K. 2007. Histogram Citra. Ilmu Komputer. Diakses 29 Maret $2017 \quad$ dari http://amutiara.staff.gunadarma.ac.id/Downloads/files/39978/ Bab-6_Histogram+Citra.pdf

Ariyanto, Nugroho. 2011. Fisiografi dan Stratigrafi Cekungan Sumatera. Bandung: ITB Bandung

Best, et al. 1994. The Relationships between the Velocities, Attenuations, and Petrophysical Properties of Reservoir Sedimentary Rocks. Geophysical Prospecting, vol. 42, 151178.

Biantoro, Elan. 2013. Kompas.com: Cadangan Minyak Indonesia Tinggal 3.7 Miliar Barrel. Diakses pada tanggal 29 Januari 2017 http://bisniskeuangan.kompas.com/read/2015/09/07/07350002 6/Cadangan.Minyak.Indonesia.Tinggal.3.7.Miliar.Barrel

Conybeare, C. E. B. (1967). Influence of Compaction on Stratigraphic Analysis. Buletin of Canadian Petroleum Geology, vol.15, 331-345

Darcy, H. 1856. Les Fontaines Publiques de la Ville de Dijon: exposition et Application. Victor Dalmont

Degruyter, W.; et al. 2010. Synchorotron X-Ray Microtomography and Lattice Boltzmann Simulation of Gas Flow Through Volcanic Pumice. Geosphere 6 pp.470-471

Djonoputro, B. Darmawan. 1984. Teori Ketidakpastian. Bandung: ITB

Gonzales, RC. dan Woods, R.E., 2002, Digital Image Processing, New Jersey: Prentice-Hall, Inc

Handoyo, et al. Digital Rock Physics Aplication: Structure Besarans Caracterization, Materials Identification, Fluid Modeling, and Elastic Properties Estimation of Saturated Sandstone. Faculty of Minning and Petroleum Enginnering Institut Teknologi Bandung, Faculty of Mathematics and Natural Sciences Institut Teknologi Bandung, Departemen of Physics, UIN Sunan Kalijaga.

Kachlrieß, M. 2008. Micro-CT in Molecular Imaging I. (pp. 2352). Springer Berlin Heidelberg

Keelan, D.K. 1982. Core Analysis for Aid in Reservoir Description. Journal of Petroleum Technology, 34, 2-483

Koesoemadinata, R.P. 1980. Geologi Minyak dan Gas Bumi, Jilid 1 edisi kedua. Bandung: ITB.

Otsu, Nobuyuki. 1979. A Threshold Selection Method from GrayLevel Histograms. IEEE Vol.9 No.1 Hal.62-68.

Putra, D. 2010. Pengolahan Citra Digital. Penerbit ANDI: Yogyakarta.

Sheriff, R.E. and Geldart, L.P. 1995. Exploration Seismology. $2^{\text {nd }}$ edition: Cambridge University Press.

Sismanto. 2012. Handout Kuliah Fisika Batuan. Yogyakarta: Prodi Geofisika UGM

Sutoyo, T., Mulyanto, E., Suhartono, V., Nurhayati, O. D., \& Wijanarto, 2009, Teori Pengolahan Citra Digital, Penerbit Andi, Yogyakarta.

Winardhi, Chandra Widyananda. 2016. Pengembangan Teknik Akuisisi, Rekonstruksi, dan Analisis Digital Sampel Core Plug Reservoir Batupasir Ukuran Besar. Bandung: FMIPA ITB. 
THIS PAGE INTENTIONALLY LEFT BLANK 